\title{
INFLUENCE OF LEADERSHIP COMPETENCIES ON PERFORMANCE OF TEA COMPANIES IN NANDI COUNTY, KENYA
}

\author{
Chikamai, Maureen Mutsachi ${ }^{1}$, \\ Makhamara Felistus ${ }^{2 i}$ \\ 'Student, \\ School of Business, \\ Kenyatta University, \\ Kenya \\ ${ }^{2}$ Dr., Lecturer, \\ School of Business, \\ Kenyatta University, \\ Kenya
}

\begin{abstract}
:
In Kenya, there is evident declining results in the Tea sector in regard to sector competitor's prices from competing countries, commitment of workers and declarations of bonuses. On the same note, although tea earns the country the second largest share of export, there has been inefficiency in production and insufficient demand for sale volume of tea over the last decade. The study aimed to determine the effect of leadership competencies on Tea Company's performance in Nandi County, Kenya. Strategic leadership theory was used to explain the interrelationship between variables. Empirical literature reviewed scholarly studies on leadership and its relationship with organizational performance. Descriptive research methodology was used. The unit of analysis were the management staff at the 9 tea organizations in Nandi County who total to 121 . The survey adopted a census study of all 121 respondents for the population was small and manageable. Semi structured questionnaire through the self- administration method was used to collect data from the primary sources. Both content and construct validity were determined. The research results add value to the areas of strategic leadership and tea sector performance. The study found that most of the tea factories management uses guiding vision statement, mission statements, firm's objectives and tea factory's guiding principles to guide their strategic direction. The research study concluded leadership competencies significantly and positively affects performance of Tea factories. The study recommended that the management of Tea factories should focus
\end{abstract}

i Correspondence: email chikamai2012@gmail.com, hilda.makhamara@ku.ac.ke, khashielehati@gmail.com 
on developing an organization's path through the creation of a vision, purpose, and core values through strategic leadership.

JEL: L10; L20; L26

Keywords: competencies, performance, leadership competencies

\section{Introduction}

Strategic leadership strategies need to resolve global instability, complexity, and data overload that require adaptability and scheduling in order to optimize corporate success. Skills in leadership strategy are important in the current competition world predicted for the century in the 21st. The source of sustainable competitive advantage is human and social resources, and therefore should be nurtured and produced with care (Hambrick, 2011). The fast and efficient information exchange in today's new, interconnected economy is the source of success. According to Aronson, McCarthy, Halawi (2015) sustainable competitive advantage is no longer built into the natural resources and properties, but into efficient intellectual capital channeling. The volatile, turbulent, uncertain, complex and heterogeneous competitive markets and global business environments have been in recent years. Thus, businesses have introduced valuable skills, capacities and techniques for their company processes and practices to promote excellence in industry, promote competitive growth, achieve corporate success, enhance corporate life, and promote corporate sustainability.

Strategic leadership is an ability to convince others to make daily voluntary choices that facilitate a company's long-term sustainability and maintain its financial feasibility in the short period of time. African Leaders Daresalaam Forum, which was organized under the theme 'Conference Challenges of Transformation Africa' by Uongozi Institute in collaboration with Benjamin Mkapa (Former Tanzanian president) agreed that Africa requires leaders who can address differences creatively, inclusively and effectively, to achieve a transformation. According to ECA-Economic Commission for Africa (2014), they agreed on Africa's need for leaders to turn these ideas into action and not lack ambition and ideas.

The researchers' motivation is driven by the fact agriculture is the backbone and the major driver of the economy of this country and yet the industries that are reliant on agricultural farm products are encountering a myriad of challenges. These challenges are to a very large extent affecting their performance and consequently slowing down growth in the country's economy. Although the challenges bedeviling the tea industry particularly in Rift Valley region in Kenya are wide, the issue of strategic leadership cannot be simply wished away. It is essential that this study be carried to determine the tea sector performance correlation with the strategic leadership practices in Nandi County being the hub and main region under KTDA with the largest tea growing but poorly performing in Kenya. 
In the North Rift of Kenya, Nandi County covers an area of 2.884.4 square kilometers. The county has an estimated population of 752,965, and for most people, tea forms the main source of income for it is the primary cash crop. It is noteworthy, however, that the production of tea in Nandi County faces several challenges (Annual KTD report, 2017/2018). In the past, Nandi County has experienced negative variations in the productivity of tea. This trend continued, despite the efforts of tea businesses and farmers to develop ways and method to combat that. The problem has been exacerbated by the county's economic development, as the farmers' primary source of income is tea increasing (Tea board Kenya report, 2018). Tea factories in the county are also facing challenges as tea prices fall while production costs rise.

Tea estates have tried in the county of Nandi to increase productivity by implementing new technologies that mitigate the growing production costs, foster innovation such as mechanical tea selection and develop new products to remain competitive in the marketplace. A remarkable example of this is the Chemartin Tea Company in Nandi County which has applied mechanization in tea plucking. In Nandi County, all these problems with teas add to the desire to provide productive and visionary, management, motivating and transforming leadership in Tea Estates in Nandi County.

\section{Statement of the Problem}

The Kenyan Tea industry has seen a shrinking inclination in terms of results on bonus reports, competition with other countries which produce tea, inadequate engagement, inefficient production and insufficient markets to sell tea in the last ten years, despite tea being Kenya's second largest export commodity. Kenya's tea industry is usually focussed on the challenges that hinder tea industry success, especially in Nandi County. Certain of these are related to productivity, performance, amount of sales and share of the produce to the market. As a result of the pay row, Nandi Tea Estate loses almost 150 million a year (Tanui, Feng, Wang \& Kipsat 2012). In 2014 exports of Ksh 2.3 billion was done, Nandi tea estate exported 2.5billion worth of tea in 2015. However, a decline was witnessed in 2016 and 2017 to 2.4 and 2.35 respectively. The shareholders' dividend for 2014, 2015, 2016 and was Kshs.14, Kshs.16, Kshs.16 and Kshs.15 respectively (Tea Board of Kenya report, 2018). Nandi tea estates need to secure an alternative market for their produce.

Studies in this area include Perez-Batres (2019) who focused on strategic leadership and performance but focused on different variables such as non-commitment of employees, ineffective use of resources, among others. This study presents the conceptual gaps on the leadership competencies on performance. In the study on formulation and implementation of the strategy, Azhar, Ikram, Rashid and Saqib (2013) concentrated on the role of leadership. However, the report failed to concentrate on the impact of performance of the organizations and strategic leadership practices, so it creates a conceptual gap that was covered by the current analysis. Finally, Makhamara 
(2016) concentrated on the role of strategic leadership in human resource management in the successful implementation of strategies in the level five public hospitals in Kenya and found that strategic leadership was a key driver for the effective implementation of strategies. The study similarly did not study the changes in organization performance as a result in unit changes in strategic leadership practices. The study also presents a conceptual gap that was covered by the current study.

\section{Objective of the Study}

The objective of the study was to find out the influence of leadership competencies on performance of Tea Companies in Nandi County, Kenya.

\subsection{Theoretical Review}

The study was anchored on strategic leadership theory. Baetz and House (1979) developed this theory. Strategic leadership allows corporate leaders to build and recreate explanations for the continued life of the organization. The development of a strategic intention and strategic task, and effective strategic actions to develop strategies and execute strategies, which generate strategic competitiveness and over average returns, is formed, according to Kirmi and Minja (2010). Many scholars have shown considerable attention to leadership especially in strategy development as expressed in Bradley and Barrick's works (2018).

Ahmed (2013) suggests that strategic leadership comprises both strategy and management roles where TMT works in strategic questions as partners. Strategic leaders must be willing, according to Gill (2011), to create a vision, mission, objectives and culture of the organization and to track progress and environmental changes in order to ensure strategies are oriented, meaningful and legitimate. This theory was significant for this analysis, since it results in effective communication of organizational performance strategic direction. According to this theory strategic leadership must provide a strategic direction that will improve the performance of a firm. Therefore, this theory supports the variable on strategic direction and organizational performance.

\subsection{Empirical Review}

Batti (2016) conducted research on the challenges that local NGOs face in terms of human Resource growth. The study concluded that non-profit organizations/ non-governmental organizations should borrow and contextualize best and promising human resource planning techniques used by non-profit organizations in order to support the advancement of non-profit organizations' human resource issues. The study left a gap on examining the correlation between leadership skills and organizational performance. The study was purely descriptive. The current study was conducted a causal-effect analysis between leadership competencies and organizational performance to bridge the methodological gap. 
The role of leadership competencies on the transition of public service reform initiatives was investigated by Achoch, Gakure, and Waititu (2015). Using questionnaires, the exploratory analysis was performed on 178 civil servants stationed in Nairobi. A leadership competency is significant in terms of both perceptions of leader effectiveness and follower satisfaction, according to the report. The findings also revealed that successful public sector management reforms have often relied to some extent on leadership competencies behaviors, and that leaders with disruptive characteristics inspire their followers to perform above and beyond expectations and articulate highperformance expectations. Employee loyalty and corporate citizenship attitudes were positively affected by leaders who exhibited transformational qualities.

Shafie, Baghersalimi, and Barghi (2015) examined into the correlation between leadership skills and success in the Tehran province's Real Estate Registration. The research was performed on 277 employees of the Tehran Real Estate Registration using a descriptive correlation process. Employee productivity is positively impacted by both development-oriented and pragmatic- oriented self-awareness leadership competencies, according to the findings. Leadership competencies with a high level of self-awareness had a stronger link to success. Pragmatic Leadership skills were more effective in a static environment and less successful in a dynamic environment than other leadership skills. The company was thrown into turmoil due to a lack of laissez-faire leadership skills.

Koch and Namusonge (2015) investigated the effect of laissez-faire, transactional, and self- awareness leadership competencies on state-owned company success in Kenya. The descriptive study used questionnaires to look at the perspectives of middle and senior managers in thirty (30) state-owned companies. Koch and Namusonge (2015) investigated the effect of laissez-faire, transactional, and self-awareness leadership competencies on state-owned company success in Kenya. The descriptive study used questionnaires to look at the perspectives of middle and senior managers in thirty (30) state-owned companies.

Voon, Lo, Ngui, and Ayob (2015) investigated the impact of self-awareness leadership competencies on employee work satisfaction in Malaysian government agencies. Using questionnaires, the research was performed on 200 Malaysian executives employed in the public sector. Self-awareness leadership competencies have a positive relationship with job satisfaction in government organizations, while transactional selfawareness leadership competencies have a negative relationship with job satisfaction. Only the contingent reward component of transactional Leadership competencies has a substantial relationship with two dimensions of job satisfaction, according to the regression results (working condition and work assignment).

The effect of creation of human capital on the performance of Kenyan insurance companies and commercial banks was assessed by Munjuri, Ogutu and K'Obonyo (2015). The cross-sectional model overview and the survey through censuses of 43 registered business banks and of 45 Kenyan insurance undertakings were used. The research showed that the impact of human resources on company results is statistically important. The study focused on insurance and commercial prohibitions, because there are 
qualitative differences in the correlation between strategy in leadership and organization performance between Kenya's tea companies. These contextual gaps have been addressed in the current analysis.

Yusuph (2015), based on a research analysis and descriptive research design with 45 participants, examined the impact of capital investments on results in the Mkwawa branch of the Tanzania national microfinance bank in the Iringo region. According to the findings, there is a clear connection between human capital expenditure and revenue. Whereas the current study was conducted in Tanzania National microfinance bank, the current study will be conducted among the tea companies in Kenya, hence addressing the existing contextual gaps.

\subsection{Conceptual Framework}

\begin{tabular}{|l|l|l|}
\hline Leadership Competencies & $\begin{array}{l}\text { Organizational Performance } \\
\text { - Career development }\end{array}$ \\
\cline { 2 - 2 } - Training and development & - Revenue growth \\
- Performance appraisal & $\begin{array}{l}\text { - Expenditure efficiency } \\
\text { - Market size } \\
\end{array}$ \\
& - Internal business growth \\
\hline
\end{tabular}

Figure 2.1: Conceptual Framework

Leadership in the organization play stewardship role in the organization which involves control in terms of providing strategic direction (Alayoubi, Al Shobaki \& Abu-Naser, 2020). The study dependent variable was organizational performance, which was measured by, revenue growth, expenditure efficiency, market size and internal business growth. This measure included both financial measures and nonfinancial measures based on the BSC Models (Kaplan \& Norton,1996).

\subsection{Research Design}

The research design is the fundamental plan which provides a summary of the exercises required to implement the research report. A descriptive research design was applied. A descriptive research design according to Cooper and Schindler (2013) describes what, where, and how a phenomenon occurs.

\subsection{Target Population}

According to Mugenda and Mugenda (2013) whole group of persons, cases or objects with certain common observable properties forms a target population. The management staff among the 9 tea firms in Nandi County who total to 121 formed the target population for this study. Unit of observation were the 9 tea factories in Nandi County while the unit of analysis were all management employees in top, middle and lower level management from each of the 9 firms. 


\begin{tabular}{|l|c|c|}
\hline \multicolumn{3}{|c}{ Table 3.1: Target Population } \\
\hline Levels of Management & Population & Percentage \\
\hline Top management/senior level & 27 & 22.31 \\
\hline Middle Level management/Section Managers & 44 & 36.36 \\
\hline Lower managers/Supervisors & 50 & 41.33 \\
\hline Total & 121 & 100 \\
\hline
\end{tabular}

Source: KTDA (Nandi Hill Region).

\subsection{Sampling Techniques}

Sampling techniques include a variety of approaches to help minimize the amount of data obtained by only taking data from a subgroup and not any possible cases or elements into account. A population of less than 200, a census is recommended (Mugenda \& Mugenda, 2013). The study therefore used a census.

\subsection{Data Collection Instruments}

Regarding its effects on the performance of tea enterprises in Nandi County through strategic leadership practices, questionnaires with closed options in Likert scale as well as open choices were used. The questionnaire constructed to capture the study objectives as reflected in section 1.3 on specific objectives.

\subsection{Data collection Procedures}

Prior to data collection the research obtained authorization letters from Kenyatta University and NACOSTI. Both survey respondents were administered individually by the researcher. In this study, focus and control were exercised in order make sure that all the instruments for data collection were availed to the participants. A drop and a pick approach were applied in this study. A period of 12 days was enough to fill and return the questionnaires.

\subsection{Data analysis and Data Presentation}

Quantitative data was analyzed and represented using percentages, standard deviations, means, and frequencies in SPSS (Version 22). Bar charts, graphs, and tables were used to present the data in prose format. This was achieved through the assessment of responses, calculation of the percentages of response variations and the description and interpretation of data based on study aims and expectations by using SPSS (Version 22) to convey research findings. Content analysis was used for analyzing qualitative data or component of data obtained from open questions.

The regression model used will be of the form;

$$
Y=\beta 0+\beta 1 X 1+\varepsilon
$$

Where:

$\mathrm{Y}=$ Performances of the tea industry firms in Nandi County 
X1- Leadership Competencies

$\mathrm{B} 1$, =regression co-efficient

$\mathrm{B} 0$ is the $\mathrm{Y}$ intercept

$\varepsilon$ is the error term

\section{Research Findings and Discussion}

\subsection{Response Rate}

The study targeted 121 respondents who consisted of senior level managers, middle level Managers and lower level managers. The researcher managed to collect 109 completely filled questionnaire. This represented $90.08 \%$ response rate, and according to Mugenda and Mugenda (2010) more than $80 \%$ response rate is an excellent response rate. Therefore, the researcher continued with data analysis process for the response was enough to draw inferences.

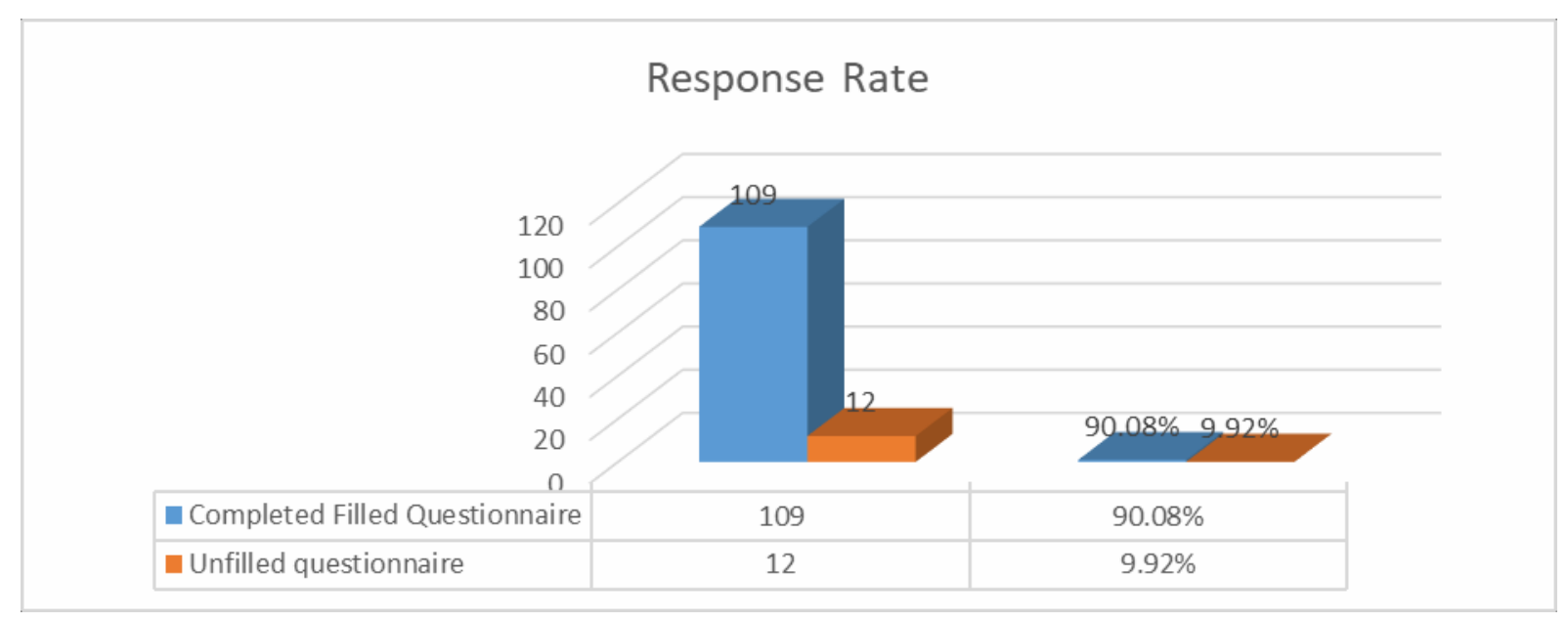

\subsection{Descriptive Analysis}

\subsubsection{Leadership Competencies and Organizational Performances}

The results in table 4.1 presents how leadership qualities affect the performance of the tea Factories in Nandi Tea factories, Kenya.

Table 4.1: Leadership Qualities

\begin{tabular}{|l|c|c|}
\hline Leadership Qualities & Frequency & Percent \\
\hline Very low extent & 6 & 5.5 \\
\hline Low extent & 6 & 5.5 \\
\hline Moderate & 8 & 7.4 \\
\hline Great extent & 8 & 7.4 \\
\hline To a very great extent & 72 & 66.2 \\
\hline Total & 109 & 100.0 \\
\hline
\end{tabular}

The results indicate that majority 66.2 per cent of the respondents felt that to a great extent leadership quality affects to a great extent the performance of tea factories. According to 
Achoch, Gakure, and Waititu (2015), a leadership competency is crucial in terms of both leader effectiveness aspirations and follower satisfaction. The findings also revealed that effective public sector management reforms rely on leadership skills and attitudes to some degree, and that disruptive leaders encourage their followers to perform above and beyond expectations and express high performance expectations. Employee loyalty and corporate citizenship attitudes were positively affected by leaders who exhibited transformational qualities. The respondents were asked to rate how much the following leadership skills influenced the performance of tea factories. The results are shown in Table 4.2.

Table 4.2: Leadership Competencies

\begin{tabular}{|l|c|c|c|c|c|}
\hline & $\mathbf{N}$ & Minimum & Maximum & Mean & Std. Deviation \\
\hline Training and development level & 109 & 1 & 5 & 4.82 & 1.409 \\
\hline Career development & 109 & 1 & 3 & 4.45 & .536 \\
\hline Performance appraisal & 109 & 1 & 3 & 4.34 & .513 \\
\hline Rewards and compensation & 109 & 1 & 5 & 4.65 & .516 \\
\hline Average & $\mathbf{1 0 9}$ & & & $\mathbf{4 . 5 6 5}$ & .744 \\
\hline
\end{tabular}

Source: Survey Data (2021).

The results indicate that to a great extent training and development of employees greatly affected tea factories Performance (Mean=4.82, Std Dev=1.409), Career Development to a very high extent (Mean=4.45, Std $\mathrm{Dev}=0.536$ ), Performance appraisal to a high extent (Mean=4.34, Std Dev=0.513) and rewards and compensation to a very high extent (mean=4.65, Std Deviation=0.516). On average it was established that leadership competencies had a great influence on tea factories performance. Shafie, Baghersalimi, and Barghi (2015) found that having both a development-oriented and a pragmaticoriented self-awareness leadership competency has a positive effect on employee success. Pragmatic Leadership skills were more effective in a static environment and less successful in a dynamic environment than other leadership skills. According to Voon, Lo, Ngui, and Ayob (2015), self-awareness leadership competencies have a positive relationship with work satisfaction in government organizations, while transactional selfawareness leadership competencies have a negative relationship.

Generally, on aspects of leadership competencies, majority of the respondents argued that Leadership competences are respected if a person shows competences that are sufficient time and frequency to become effective in the situation as to self-awareness, self-management, social awareness and social skills. Frameworks, which show that emotional intelligence is a major component of global leadership competence, are most common in existing competences. In line with these personal characteristics, knowledge and skills are used, which underlie and determine how and when. 


\subsection{Tea Factories Performance}

The study sought to evaluate the performance of Tea factories in Nandi County, Kenya. The indicators of performance included; revenue, expenditure efficiency, market size and internal business growth.

Table 4.3: Performance of Tea Factories

\begin{tabular}{|l|c|c|c|c|c|}
\hline & $\mathbf{N}$ & Minimum & Maximum & Mean & Std. Deviation \\
\hline Revenue growth & 109 & 1 & 5 & 4.11 & .6872 \\
\hline Expenditure efficiency & 109 & 1 & 5 & 4.03 & .8100 \\
\hline Market size & 109 & 1 & 5 & 4.26 & .9179 \\
\hline Internal business growth & 109 & 1 & 5 & 4.76 & 1.2758 \\
\hline Average & & & & $\mathbf{4 . 2 9}$ & $\mathbf{. 9 2 2 7}$ \\
\hline
\end{tabular}

The study results indicate that the revenue growth in majority of the factories was realized (Mean=4.11, Std Dev=0.6872). Increased produce, according to the respondents, had an effect on the quality and quantity of products supplied for processing. By increasing income levels, the factory's output optimization reduced losses and increased farmer satisfaction, which can be attributed to lower average production costs and higher revenues. The findings also indicated that there was expenditure efficiency (mean=4.03, std dev $=0.8100$ ) which was reflected in Restricted waste wasting and set-up time ensured, before, during and after tea production, both the right quality and quantity was improved. In the case of raw material (green tea leaf) the respondents submitted that it needs timely handling and proper tracking to ensure quality made tea. These has resulted to improved market size (Mean=4.26, Std dev=.9179). The study also established that internal business growth in the 9 tea factories targeted was ensured (mean= 4.76, Std Dev=1.2758). The respondents argued that there has been growth witnessed in the numer of machines, factories and new buildings developed within a period of 5 (five) years. The study established that cost and misappropriation of material is controlled through material management. According to the research findings, tea prices average $240 \mathrm{Ksh}$ per $\mathrm{kg}$ in the Kenyan market. The per-kilogram cost of output is $69 \mathrm{Ksh}$. The amount of production goals is important, and the conversion rate needs to be improved. The volume of rejected leaves is manageable on a regular basis. Kenya's power costs remain high, necessitating more reductions in power costs, either by tariff changes or the introduction of new technologies.

\subsection{Correlation Analysis}

The correlation analysis presents the nature and strength of relationship amongst the study variables. 


\begin{tabular}{|l|l|c|c|}
\hline \multicolumn{3}{|c}{ Table 4.4: Correlation Analysis } \\
\hline \multirow{3}{*}{$\begin{array}{l}\text { Leadership } \\
\text { Competencies }\end{array}$} & $\mathrm{N}$ & Leadership Competencies & Performance \\
\cline { 2 - 4 } & Pearson Correlation & & \\
\cline { 2 - 4 } & Sig. (2-tailed) & & \\
\hline \multirow{3}{*}{ Performance } & $\mathrm{N}$ & & \\
\cline { 2 - 4 } & Pearson Correlation & & \\
\cline { 2 - 4 } & Performance Sig. (2-tailed) & & \\
\hline
\end{tabular}

The findings in this study indicates that the correlation between leadership competencies and performance of tea factories was positive and significant $(\mathrm{P}=0.605$, sig=0.001). The results were supported by Ng'ang'a (2018) that leadership competencies greatly influence organizational performance. Agwu (2015) supported that mission and vision, leadership, ethics and control strongly influence organizational performance.

The study model summary presents the correlation coefficient and coefficient of determination. The correlation coefficient presents the strength of the relationship between variable while the coefficient of determination explains the extent with which the dependent variable is explained by changes in the independent variable.

Table 4.5: Model Summary

\begin{tabular}{|c|c|c|c|c|}
\hline Model & R & R Square & Adjusted R Square & Std. Error of the Estimate \\
\hline 1 & $969 \mathrm{a}$ & 940 & 937 & 1.11118 \\
\hline
\end{tabular}

a. Predictors: (Constant), Leadership Competencies

The study results indicate that the correlation coefficient (R) was $96.9 \%$ indicating that there was a strong relationship between study variables. The coefficient of determination (adjusted R squared=0.937) indicates that 93.7 per cent changes in the performance of Tea factories was explained by the changes in leadership competencies. $6.3 \%$ variation in the performance of Tea Companies is affected by other factors not in the Model.

Table 4.6: Regression Coefficients a

\begin{tabular}{|c|c|c|c|c|c|}
\hline \multirow{2}{*}{ Model } & \multicolumn{2}{|c|}{ Unstandardized Coefficient } & \multirow{2}{*}{$\begin{array}{l}\text { Standardized } \\
\text { Coefficient Beta }\end{array}$} & \multirow{2}{*}{$\mathbf{t}$} & \multirow{2}{*}{ Sig. } \\
\hline & B & Std. Error & & & \\
\hline (Constant) & 16.163 & 1.256 & \multirow{2}{*}{532} & 12.871 & .000 \\
\hline 1. Leadership Competencies & 1.230 & 088 & & 14.054 & .000 \\
\hline
\end{tabular}

a. Dependent Variable: Performance of Tea Factories

The adopted Study Model was Y=16.163+1.230X3.

The results as summarized in the model indicates that holding leadership competencies and ethical practices constant the performance of tea factories would be 16.163 units. The findings indicate that the relationship between leadership competencies and organizational performance was positive and significant $(\beta 3=1.230$, sig $=0.000)$. A unit change in leadership competencies results to 1.230 unit changes in tea factory performance. The findings supported Shafie, Baghersalimi and Barghi (2015) leadership competency has a positive impact on organizational performance. The concurs with 
Voon, Lo, Ngui and Ayob (2015) that leadership competencies have a positive relationship with job satisfaction.

\section{Conclusions and Recommendations}

\subsection{Conclusions}

Leadership competencies had a positive and significant relationship with Tea factories performance. Strengthening leadership competencies at the corporate level could be a viable choice for Kenya, a nation afflicted by major leadership challenges such as corruption and resource misallocation. Better tea sector efficiency, owing to strong leadership, will contribute to improved economic performance, which will benefit the entire country. Furthermore, improved efficiency will result in faster, more reliable, and profitable tea service delivery to residents, which is beneficial because state companies that provide utility services are not subject to private sector competition.

\subsection{Recommendations}

Tea factory strategic leaders should focus on developing an organization's path through the creation of a vision, purpose, and core values. Furthermore, effective leadership is suggested; without effective leadership, anything people do is likely to fail; but, with effective leadership, the future is continuously built anew for the people and society. One of the big and serious challenges facing the tea industry in the twenty-first century is visionary leadership, which is an element of strategic leadership.

\section{Conflict of Interest Statement}

The authors declare no conflicts of interests.

\section{About the Author}

I am a Certified Credit professional with a Bachelor of Commerce degree - Finance option and currently pursuing Masters in Business Administration - Strategic Management option. I have an interest in Strategic Decision Making and currently equipping myself on Key Management Models.

\section{References}

Aguinis, H., \& Kraiger, K. (2009). Benefits of training and development for individuals and teams, organizations, and society. Annual review of psychology,60, 451-474.

Ahmed, S. (2013). Effective not-for profit management: Context, concepts, and competencies. CRC Press Taylor \& Francis: New York. 
Azhar, A., Ikram, S., Rashid, S., \& Saqib, S. (2013). The role of leadership in strategy formulation and implementation. International journal of management $\mathcal{E}$ organizational studies, 1(2).

Finkelstein, S., Hambrick, D. C., \& Cannella, S. A. (2018). Strategic Leadership: Theory and Research on Executive. New York: Oxford University Press.

Jooste, C., \& Fourie, B. (2009). The role of strategic leadership in effective strategy implementation: Perceptions of South African strategic leaders. Southern African Business Review, 13(3).

Perez-Batres, L. A. (2019). Radical Institutional Change: Foreign Firms Strategic Responses to Regulatory Punctuations in Emerging Markets. Journal of Management Policy and Practice, 20(2).

Trochim, W. K., \& Donnelly, J. P. (2016). The Research Methods Knowledge Base (3rd ed.). Boston: Cengage Learning.

Waithira, L., Waiganjo, E., \& Njeru, A. (2017). Influence of strategic direction on organizational performance in tourism government agencies in Kenya. International Journal of Business and Commerce, 6(4), 18-36. 
Chikamai, Maureen Mutsachi; Makhamara Felistus

INFLUENCE OF LEADERSHIP COMPETENCIES ON PERFORMANCE

OF TEA COMPANIES IN NANDI COUNTY, KENYA

Creative Commons licensing terms

Authors will retain copyright to their published articles agreeing that a Creative Commons Attribution 4.0 International License (CC BY 4.0) terms will be applied to their work. Under the terms of this license, no permission is required from the author(s) or publisher for members of the community to copy, distribute, transmit or adapt the article content, providing a proper, prominent and unambiguous attribution to the authors in a manner that makes clear that the materials are being reused under permission of a Creative Commons License. Views, opinions and conclusions expressed in this research article are views, opinions and conclusions of the author(s). Open Access Publishing Group and European Journal of Economic and Financial Research shall not be responsible or answerable for any loss, damage or liability caused in relation to/arising out of conflict of interests, copyright violations and inappropriate or inaccurate use of any kind content related or integrated on the research work. All the published works are meeting the Open Access Publishing requirements and can be freely accessed, shared, modified, distributed and used in educational, commercial and non-commercial purposes under a Creative Commons Attribution 4.0 International License (CC BY 4.0). 